\title{
PERAN SEKRETARIS DALAM MENYELESAIKAN \\ TUGAS ADMINISTRASI FAKTURIS \\ PADA PT DWI ANUGERAH ABADI
}

\author{
Oleh : \\ Siti Zubaidah, S.d, M.Pd.i \\ Dosen Sekretari Universitas Pamulang \\ dan \\ Jessy Okctarina Panjaitan \\ Mahasiswi Sekretari Universitas Pamulang
}

\begin{abstract}
Abstrak
Di era globalisasi ini, profesi sebagai seorang sekretaris masih saja dianggap sebelah mata dan menjadi bahan pergunjingan baik di dalam maupun di luar lingkungan kantor. Hal ini mungkin terpengaruh dari gambaran sosok sekretaris yg identik dengan perempuan, rok mini, dan pemikiran akan adanya hubungan intim antar sekretaris dengan pimpinannya. Seorang sekretaris adalah sistem pimpinan yang memiliki keahlian mengurus kantor, menampilkan kemampuan menerima tanggung jawab tanpa diarahkan sesuai dengan ruang lingkup wewenang tugasnya. Proses penyeleksian seorang sekretaris tersebut dapat dinilai dari knowledge, skill dibidangnya, seperti keahlian mengetik dengan 10 jari, surat-menyurat, mengarsip menggunakan system yang baik.
\end{abstract}

\section{A. Pendahuluan}

Berdasarkan uraian diatas mengenai sekretaris, maka secara umum sekretaris adalah seorang karyawan atau pegawai yang diangkat oleh pimpinannya sebagai pembantu dalam hal menyediakan suatu pekerjaan, bisa mengatasi kesibukan dan memecahkan kesulitan, serta mempercepat proses penyesuaian pekerjaan sehingga bisa dicapai hasil yang diharapkan.

Adapun pengertian sekretaris secara umum lainnya, yaitu sekretaris merupakan pembantu pimpinan yang dapat mengerjakan tugas - tugas kantor, pekerjaan kantor, memegang rahasia perusahaan dan tanggung jawab yang tinggi di kantor atau perusahaan, karena dianggap dapat dipercaya dalam mengerjakan tugastugas pimpinan, dimana pimpinan tersebut memiliki tugas dan tanggung jawab yang besar dalam memimpin dan mengelola organisasi atau perusahaan dari mengurus perjanjian, administrasi serta melayani tamu.

Administrasi sering dikaitkan dengan urusan yang pengaturan atau pengurusan terhadap suatu bidang tertentu yang kemudian hasilnya akan dibutuhkan pada bagian 
tersebut. Administrasi pada penerapan unsur di dalamnya melingkupi setiap kegiatan yang terdiri dari pengaturan hingga pengurusan terhadap sekelompok orang yang memiliki diferensiasi pekerjaan untuk mencapai sebuah tujuan bersama. Administrasi dapat berjalan dengan dua atau banyak orang yang terlibat di dalamnya.

Setiap organisasi, baik yang berorientasi pada keuntungan maupun organisasi yang tidak berorientasi pada keuntungan dapat dipastikan mempunyai suatu unit khusus yang bertugas dalam bidang administrasi. Dengan kata lain setiap organisasi pasti memerlukan suatu unit yang mengelola segala sesuatu yang berhubungan dengan kegiatan administrasi yang pada akhirnya akan berhubungan dengan kegiatan mengelola faktur. Menurut Agus Sugiarto (2005:2) mengatakan kegiatan administrasi pada dasarnya adalah menghasilkan, menerima, mengolah dan menyimpan berbagai surat, laporan, formulir dan sebagainya.

Administrasi adalah usaha dan kegiatan yang berkenaan dengan penyelenggaraan kebijaksanaan untuk mencapai tujuan. Administrasi dalam arti sempit adalah kegiatan yang meliputi : catat-mencatat, surat-menyurat, pembukuan ringan, ketik-mengetik, agenda, dan sebagainya yang bersifat teknis ketatausahaan. Administrasi dalam arti luas adalah seluruh proses kerja sama antara dua orang atau lebih dalam mencapai tujuan dengan memanfaatkan sarana prasarana tertentu secara berdaya guna dan berhasil guna.

Di dalam kegiatan administrasi pada umumnya, administrasi berhubungan dengan kegiatan pengelolaan faktur. Pengertian faktur pada umumnya ialah dokumen yang digunakan sebagai pernyataan tagihan yang harus dibayar oleh customer. Dalam bentuk sederhana dikenal dengan nama bon. Pada transaksi yang nominalnya relatif kecil, faktur digunakan langsung sebagai dokumen tagihan sedangkan pada perusahaan yang nominal transaksinya besar, biasanya dilengkapi dengan surat tagihan atau kwitansi.

Oleh karena itu, faktur sangat penting dalam kegiatan administrasi. Yang dimana setiap harinya seorang admnistrasi harus menginput faktur untuk setiap penjualan perusahaan. Agar pengelolaan faktur dapat berjalan dengan baik dan benar, maka faktur yang telah diproses harus secepatnya diserahkan kepada customer setelah menerima pengiriman barang atau jasa dari perusahaan.

PT Dwi Anugerah Abadi adalah perusahaan yang bergerak dibidang distributor sparepart mobil. Perusahaan Dwi Anugerah Abadi ialah perusahan 
berbadan hukum perseroan terbatas dan terdapat kegiatan pengelolaan faktur. Maka diperlukan suatu system informasi penjualan barang. Dengan adanya suatu system informasi penjualan barang, maka semua penjualan barang akan terpantau dan dapat diketahui seberapa banyak barang yang terjual. Dengan itu maka dibutuhkanlah proses administrasi faktur.

\section{B. Identifikasi Masalah}

Berdasarkan uraian latar belakang diatas, maka penulis mengindentifikasi masalah yaitu :

a. Peranan bagian administrasi fakturis dalam mempelancar penagihan belum berjalan secara efektif.

b. Peranan bagian administrasi fakturis dalam mengelola faktur belum berjalan sesuai prosedur yang ada.

c. Faktur-faktur penjualan yang telah dikirim dibiarkan menumpuk tidak langsung diarsipkan.

\section{Pembatasan Masalah}

Pada kenyataannya masalah yang terjadi di sebuah perusahaan karena kondisi keterbatasan waktu, dana dan tenaga penulis sendiri tidak mungkin mampu mengarahkan masalah yang terjadi secara keseluruhan maka penulis membatasi masalah yaitu: Peran Sekretaris Dalam Menyelesaikan Tugas Administrasi Fakturis Pada Pt Dwi Anugerah Abadi D. Manfaat dan Tujuan Laporan

1. Tujuan yang hendak dicapai oleh penulisan tugas akhir ini, yaitu sebagai berikut :

a. Untuk mengetahui pengadministrasian di PT Dwi Anugerah Abadi.

b. Untuk mengetahui seberapa besarnya peran sekretaris dalam pengadministrasian di PT Dwi Anugerah Abadi.

c. Untuk menambah pengetahuan, teori, dan pengalaman di bidang administrasi perkantoran khususnya administrasi fakturis.

2. Penulis diharapkan dapat memberi manfaat antara lain :

1) Bagi penulis

a) Untuk menambah pengetahuan dan ilmu dalam kesekretarisan.

b) Ilmu tentang administrasi perkantoran khususnya fakturis yang baik.

c) Untuk menambah pengalaman dalam dunia kerja yang akan dihadapi suatu saat nanti. 
2) Bagi Universitas Pamulang (UNPAM)

a) Untuk memenuhi salah satu syarat kelulusan program Diploma III (D3) Jurusan Sekretaris Fakultas Ekonomi.

b) Sebagai bahan pustaka bagi mahasiswa/i yang akan membacanya.

\section{E. Tinjauan Pustaka}

\section{Pengertian Sekretaris}

Menurut (Ramon;2005), mengatakan bahwa peran seorang sekretaris bukan hanya sebagai salah satu karyawan dalam sebuah perusahaan, melainkan sebagai faktor penting yang mendukung kelancaran tugas-tugas pimpinan karena sebagian tugas sekretaris adalah berkaitan erat dengan pimpinan.

Sekretaris adalah seorang pembantu dari seorang kepala atau pimpinan yang menerima pendiktean, menyiapkan surat-menyurat, menerima tamu, memeriksa, atau mengingatkan pimpinannya mengenai kewajibannya yang resmi atau perjanjiannya dan melakukan banyak kewajiban lainnya yang berhubungan guna meningkatkan efektifitas dari pimpinannya mengenai kewajiban lainnya yang berhubungan untuk meningkatkan efektivitas pimpinannya.

Menurut Dr. Durotul Yatimah, M.PD. (2013:29) Istilah sekretaris, menurut Prayudi Atmosudirdjo dalam bukunya Kesekretarisan dan Administrasi Perkantoran, diambil dari bahasa latin 'secretum', yaitu 'rahasia'. Secara sederhana, sekretaris bisa diartikan sebagai seseorang yang bisa dipercaya, seseorang yang dapat menyimpan rahasia atau sebagai pegawai yang menangani hal-hal yang bersifat rahasia (confidential employee).

Sutarto, dalam Sekretaris dan Tatawarkat, mengutip beberapa pendapat tentang pengertian sekretaris dari para ahli.

a. Menurut H.W.Fowler dan F.G.Fowler, dalam bukunya Sutarto Sekretaris :

a) Orang yang bekerja pada orang lain untuk membantu pekerjaan korespondensi, pekerjaan tulis, mendapatkan informasi, dan masalah-masalah rahasia lainnya.

b) Pegawai yang ditunjuk masyarakat atau perusahaan atau perserikatan untuk melakukan korespondensi, memelihara warkat-warkat, terutama yang berurusan dengan perusahaannya.

c) Menteri yang mengepalai kantor pemerintahan-menteri di Amerika Serikat dan Vatikan.

b. Menurut Louis C.Nanassy dan William Selden, dalam bukunya Sutarto 
Sekretaris: Seorang pegawai kantor yang memiliki kedudukan lebih bertanggung jawab daripada seorang stenografer dan tugas-tugasnya biasanya meliputi pengambilan dan penyalinan dikte; berurusan dengan publik untuk menjawab telepon, mengundang pertemuan, membuat perjanjian; dan memelihara atau mengarsip warkat-warkat, surat-surat, dan lain-lain. Seorang sekretaris sering bertindak sebagai seorang oembantu administrasi atau pimpinan muda.

c. Menurut Alvina Treut Burrows cs, dalam bukunya Sutarto.

Sekretaris :

a) Seseorang yang menulis surat dan memelihara warkat-warkat untuk orang, perusahan, dan lain-lain.

b) Pegawai pemerintah yang mengepalai suatu departemen: sekretaris departemen perburuhan.

c) Meja tulis.

d. Menurut M.Braum dan Ramon C. Portugal, dalam bukunya Sutarto

Istilah 'sekretaris' yang dipakai dalam buku ini berarti seorang pembantu dari seorang atasan yang menerima pendiktean, menyiapkan korespondensi, menerima tamu, memeriksa atau mengingatkan atasannya mengenai kewajiban yang resmi atau perjanjiannya, dan melakukan kewajiban-kewajiban lainnya yang berhubungan guna meninggalkan efektivitas atasan.

Berdasarkan pengertian para ahli diatas, kita bisa menyebutkan bahwa sekretaris adalah seseorang yang dapat dipercaya oleh pimpinan dalam membantu memperlancar pekerjaan, terutama untuk penyelenggaraan kegiatan administratif yang menunjang kegiatan manajerial pimpinan atau kegiatan operasional perusahaan, serta membantu pimpinan dalam membina tata hubungan (komunikasi) dengan bawahan maupun pihak lain yang berkepentingan dengan perusahaan.

\section{Fungsi Sekretaris}

Fungsi sekretaris dalam organisasi bisa dilihat dari tiga aspek, yaitu berdasarkan ruang lingkup tugas sekretaris, kedudukan sekretaris dalam organisasi, dan hubungan sekretaris dengan pimpinan. Fungsi sekretaris dilihat dari ruang lingkup tugasnya dibagi dua, yaitu sebagai berikut:

a. Fungsi Primer 
Fungsi primer sekretaris adalah memberikan jasa atau pelayanan jasa administratif yang menunjang kegiatan operasional organisasi/perusahaan/unit organisasi melalui keterampilan, meliputi pengetikan, penanganan telepon, pengelolaan surat dan arsip lainnya, penanganan agenda, penggandaan, dan lain-lain.

Contoh tugas : Sekretaris mengetikkan laporan yang dibuat oleh atasan. Menerima telepon, memproses surat masuk, menyimpan atau mengambil kembali arsip yang dibutuhkan oleh atasan, dan mengatur agenda kerja atasan.

b. Fungsi Sekunder

Fungsi Sekunder sekretris adalah turut menjamin kelancaran kegiatan organisasi/perusahaan serta bertanggung jawab atas aktivitas rutin kantor dengan memanfaatkan beberapa pengetahuan, misalnya bisnis perusahaan, perbankan, statistika dan keuangan, hubungan antar manusia, komunikasi, teknik persiapan rapat, dan laim-lain.

Contoh tugas: Sekretaris memberikan informasi tentang produk yang dihasilkan kepada seseorang yang membutuhkan informasi tersebut melalui telepon, membantu atasan untuk mengurus hal-hal tertentu yang berkaitan dengan bank, melakukan penyempurnaan format laporan petty cash yang dibuat setiap bulan agar lebih mudah dikaji, membina hubungan dengan baik dengan rekan seperkerjaan, berkomunikasi secara luwes dengan relasi perusahaan sehingga tercermin citra positif perusahaan tempat ia bekerja, dan membuat persiapan rapat dengan baik dan cermat.

Fungsi sekretaris diliat dari kedudukannya dalam organisasi, yaitu sebagai berikut :

a) Staf atau karyawan.

b) Respsionis.

c) Operator telepon.

d) Arsiparis

e) Typist atau pengetik.

f) Pembantu pimpinan.

g) Public relation officer.

h) Individu.

Fungsi sekretaris dilihat dari hubungannya dengan pimpinan adalah : 

a) Penjaga manajer.
a) Asisten pribadi.
b) Perawat, dan
c) Penasihat.

\section{Tugas-Tugas Sekretaris}

Menurut Saiman (2002:40), mengatakan bahwa tugas seorang sekretaris tidak hanya membantu meringankan tugas seorang pimpinan, namun seorang sekretaris juga dituntut untuk mampu dan berkompetendalam mengerjakan tugas-tugas kesekretariatannya. Seperti dalam hal korespondensi, kearsipan, dan penyelenggaraan rapat. Semua itu juga merupakan tugas sekretaris. Tugas sekretaris dalam arti sempit adalah sebagai orang yang dipercaya oleh pimpinan untuk menyimpan rahasia pimpinan. Sedangkan tugas sekretarisdalam arti luas adalah pelaksanaan tugas-tugas yang bersifat membantu manajer atau pimpinan untuk menjalankan roda organisasi, lembaga, maupun kantor.

Menurut H. W Fowler dan F. G Fowler yang dikutip oleh Nani Nuraeni dalam buku Sekretaris Professional mengemukakan bahwa sekretaris adalah orang yang bekerja pada orang lain untuk membantu dalam korespondensi, pekerjaan tulis, mendapatkan informasi dan masalah-masalah lainnya. Pegawai yang ditunjuk oleh masyarakat atau perusahaan atau perserikatan untuk melakukan korespondensi, memelihara warkat-warkat, terutama yang berurusan dengan perusahaannya.

Menteri yang mengepalai kantor pemerintah, menteri di Amerika Serikat dan Vatikan (2008:2), menjelasakan bahwa sekretaris dibanding dengan posisi lain, sekretaris termasuk karyawan yang memiliki multi tugas, di antaranya :

a. Menurut wewenangnya.

a) Tugas rutin. Meliputi pengetikan, making call, menerima tamu, korespondenci, filling, surat menyurat.

b) Tugas instruksi. Meliputi penyusunan jadwal perjalanan, making appointment, pengaturan keuangan, persiapan dan penyelenggaraan rapat, arrange schedule.

c) Tugas kreatif. Meliputi pembuatan formulir telepon, dokumentasi, mengirim ucapan kepada klien, mengatur ruang kantor pimpinan.

b. Menurut jenis tugasnya. 
a) Tugas administrasi perkantoran. Meliputi surat menyurat, pembuatan laporan, filling.

b) Tugas resepsionis. Meliputi making call, melayani tamu, menyusul jadwal pertemuan pimpinan.

c) Tugas social. Meliputi mengatur rumah tangga kantor, mengirim ucapan selamat kepada relasi, mempersiapkan resepsi/jamuan acara resmi kantor.

d) Tugas insidentil. Meliputi mempersiapkan rapat, mempersiapkan pidato, presentasi, dan mempersiapkan perjalanan dinas pimpinan.

\section{Jenis Jabatan Sekretaris}

Dalam pratiknya, terdapat dua macam sekretaris, yaitu:

a. Sekretaris organisasi (executive secretary)

b. Sekretaris pribadi (private secretary)

Kedua macam tersebut dibedakan berdasarkan luas ruang lingkup tanggung jawabnya.

a. Sekretaris Organisasi (executive secretary)

Sekretaris organisasi adalah seorang yang memimpin suatu sekretariat dari suatu perusahaan atau sekretariat dari suatu instansi pemerintah tertentu, dengan fungsi utama yaitu mengoordinasikan seluruh pelayanan adminitrasi yang menunjang kegiatan operasional perusahaan. Seorang sekretaris organisasi, disamping bekerja keras atas intruksi, kadang-kadang juga bertugas dan mempunyai kedudukan sebagai pemimpin pelaksana, yang memiliki wewenang untuk ikut membuat keputusan, pengarahan, melakukan koordinasi atas pelayanan administrasi, mengadakan pengawasan, serta melakukan penyempurnaan organisasi dan tata kerja. Dengan demikian, sekretaris organisasi harus memahami tujuan organisasi, prinsip-prinsip, dan asas-asas manajemen atau organisasi dengan baik.

Sebutan lain dari sekretaris organisasi adalah sekretaris perusahaan, kepala sekretariat, corporate secretary, atau administrator manager. Contoh sekretariat organisasi, di antaranya sekretaris jenderal, sekretaris wilayah daerah, dan sekretaris perusahaan.

Berdasarkan uraian tersebut, sekretaris organisasi memiliki cir-ciri sebagai berikut.

a) Memimpin suatu unit kerja (sekretariat)/pimpinan sekretariat instansi/perusahaan. 
b) Memiliki wewenang untuk ikut membuat kebijakan (policy).

c) Bertugas membantu melakukan fungsi manajemen (POAC), yaitu ikut membuat rencana organisasi, membuat keputusan, membuat pengarahan, koordinator pelayanan administrasi, serta melakukan pengawasan dan penyempurnaan organisasi.

d) Bertanggung jawab langsung kepada pimpinan puncak.

b. Sekretaris pribadi (private secretary) dan sekretaris pimpinan

Sekretaris pribadi tidak berstatus sebagai manajer, walaupun dia harus menjalakan manajemen terhadap bawahannya. Dia merupakan pembantu pimpinana dengan tugas utama melaksanakan tugas-tugas dari pimpinan yang bersifat pribadi. Ciri-ciri sekretaris pribadi, diantaranya :

a) Seorang pelaksana, bukan seorang pimpinan.

b) Tidak memiliki wewenang menetukan kebijakan (policy).

c) Tugasnya terbatas pada penyelenggaraan administrasi dan kegiatan perkantoran.

d) Bertanggung jawab kepada pimpinan tertentu.

Sekretaris pribadi dalam pengertian ini bukan pegawai staf dari suatu organisasi atau perusahaan, tetapi diangkat dan digaji oleh perseorangan. Contohnya sekretaris pribadi artis dan sekretaris pribadi presiden. Adapun sekretaris pimpinan merupakan seorang pembantu pimpinan tertentu, dengan fungsi utama melaksanakan kegiatan admnistrasi dan tugas perkantoran untuk kelancaran kegiatan manajerial pimpinan. Sekretaris pimpinan dalam pengertian ini diangkat dan digaji oleh organisasi yang bersangkutan.

Menurut Sutarto, dalam sekretaris dan tatawarkat, perbedaan prinsipil antara sekretaris organisasi dengan sekretaris pribadi adalah sekretaris organisasi, di samping bekerja atas perintah pimpinan, memiliki pula wewenang untuk turut membuat rencana organisasi, membuat keputusan, melakukan pengarahan, melakukan pengoordinasian, menjalakan kontrol, dan melakukan penyempurnaan organisasi dan tata kerja, serta bekerja terutama untuk kepentingan organisasi membantu melakukan fungsi manjemen tertinggi yang meliputi perencanaan, pembuatan keputusan, pengarahan, pengoordinasian, pengontrolan, dan penyempurnaan. Adapun sekretaris pribadi pimpinan, hanya melaksanakan tugas atas perintah pimpinan dan melakukan tugas yang sifatnya pribadi untuk kepentingan pimpinan. Dengan kata lain, sekretaris pribadi 
pimpinan tidak melakukan fungsi manajemen tertinggi. Di samping itu, tugas sekretaris pribadi pimpinan hanya melaksanakan kegiatan adminitrasi dan tugas perkantoran untuk kelancaran kegiatan manajerial pimpinan.

Dengan demikian, jelas bahwa wewenang sekretaris organisasi lebih luas daripada wewenang sekretaris pribadi dan sekretaris pimpinan. Jenis jabatan sekretaris, selain dibedakan menurut luas ruang lingkup tanggung jawab dan tugasnya, juga dapat dibedakan berdasarkan :

a. Kemampuan dan Pengalaman Kerja

Dilihat dari kemampuan dan pengalaman kerjanya, sekretaris dibedakan menjadi dua.

a) Sekretaris junior, yaitu sekretaris yang baru memulai karirnya sebagai seorang sekretaris dan belum memiliki banyak pengalaman kerja sebagai seorang sekretaris sehingga masih harus banyak belajar dan mendapatkan bimbingan dari sekretaris yang sudah berpengalaman atau sudah lebih dahulu ada. Selain itu, keberadaan mereka dalam bekerja pun tidak bisa dilepas secara mandiri, tetapi harus mendpatkan pengawasan dan perhatian secara saksama. Dengan kata lain, sekretaris junior biasanya dipersiapkan sebagai regenerasi jabatan sekretaris dalam organisasi.

b) Sekretaris senior, yaitu sekretaris yang sudah memiliki kemampuan kerja dan memiliki banyak pengalaman kerja sebagai seorang sekretaris. Dalam bekerja, ia tidak lagi harus mendapatkan perhatian dan pengawasan yang saksama seperti sekretaris junior, karena dapat bekerja secara mandiri sesuai dengan tugas yang diberikan kepadanya.

b. Spesialisasi Bidang Keahlian

Jenis sekretaris bisa dilihat berdasarkan spesialisasi bidang keahlian yang dimilikinya. Oleh karena itu, sekretaris jenis ini selain harus memiliki kemampuan dan keterampilan kerja sebagai seorang sekretaris, dia juga harus kapabel, terampil, dan memiliki pengetahuan khusus sesuai dengan bidang keahlian yang dimilikinya. Contohnya sekretaris bidang hukum, sekretaris bidang farmasi, dan sebagainya.

\section{Peran Seorang Sekretaris}


Sekretaris memegang peranan yang penting dan dapat menetukan berhasil tidaknya tujuan perusahaan. Pentingnya peranan seorang sekretaris ini tentunya sesuai dengan jabatan sekretaris pada masing-masing organisasi. Peranan sekretaris secara umum dapat diketahui sebagai berikut :

a. Sebagai perantara saluran komunikasi dan pembinaan hubungan yang baik bagi orang yang ingin berhubungan dengan pimpinan.

b. Sebagai sumber informasi yang diperlukan pimpinan dalam memenuhi fungsi, tugas, dan tanggung jawab.

c. Sebagai pelanjut keinginan pimpinan kepada bawahan dalam pelaksanaan tugas.

d. Alternatif pemikiran dari pimpinan dalam ide-ide.

e. Sebagai faktor penunjang dalam keberhasilan pekerjaan dan cerminan pimpinan dan bawahan.

\section{Pengertian Administrasi}

Istilah administrasi berasal dari bahasa latin yaitu "ad" dan "ministrate" yang artinya pemberian jasa atau bantuan, yang dalam bahasa inggris disebut "Administration" artinya "to serve", yaitu melayani dengan sebaik-baiknya. Jadi kata adminitrasi dapat diartikan sebagai suatu kegiatan atau usaha untuk membantu, melayani, mengarahkan, atau mengatur semua kegiatan di dalam mencapai tujuan.

Pengertian adminitrasi dapat dibedakan menjadi 2 pengertian yaitu:

a. Adminitrasi dalam arti sempit

Menurut Soewarno Handayaningrat menyatakan "adminitrasi secara sempit berasal dari kata Adminitrastie (bahasa Belanda) yaitu meliputi kegiatan catat-mencatat, surat-menyurat, pembukuan ringan, ketik-mengetik, agenda dan sebagainya yang bersifat teknis ketatausahan". Jadi dapat disimpulkan administrasi dalam arti sempit adalah merupakan kegiatan ketatausahaan serta hal-hal yang lain yang dimaksudkan untuk menyediakan informasi serta mempermudah memperoleh informasi kembali jika dibutuhkan.

b. Administrasi dalam arti luas

Menurut The Liang Gie menyatakan "administrasi secara luas adalah serangkaian kegiatan yang di lakukan oleh sekelompok orang dalam suatu kerjasama untuk mencapai tujuan tertentu". Jadi adminitrasi dalam arti luas dapat disimpulkan pada 
dasarnya semua mengandung unsur pokok yaitu adanya kegiatan dan kerjasama untuk mencapai tujuan yang telah di tentukan sebelumnya.

\section{Fungsi Administrasi}

Fungsi adminitrasi untuk mencapai efektifitas dan efisiensi yang tinngi, segala kegiatan dan tindakan harus dilaksanakan dengan pertimbangan dan perhitungan yang rasional. Untuk pencapaian tujuan yang telah di tentukan perusahaan harus mempunyai langkah-langkah kegiatan. Dan langkah-langkah kegiatan itu disebut dengan fungsi pokok. Adapun fungsi-fungsi pokok admintrasi meliputi :

\section{a. Perencanaan (Planning)}

Perencanaan merupakan salah satu syarat mutlak bagi setiap kegiatan adminitrasi. Tanpa perencanaan, pelaksanaan suatu kegiatan akan mengalami kesulitan bahkan kegagalan dalam mencapai tujuan yang diinginkan.

Menurut Hadari Nawawi dalam bukunya "Administrasi Pendidikan" bahwa perencanaan pada dasarnya berarti persiapan menyusun suatu keputusan berupa langkah-langkah penyelesaian suatu masalah atau pelaksanaan suatu pekerjaan yang terarah pada pencapaian tujuan tertentu.

Sedangkan menurut Sondang P. Siagian bahwa planning atau perencanaan dapat didefinisikan sebagai keseluruhan proses pemikiran dan penetuan secara matang daripada hal-hal yang akan dikerjakan dimana yang akan datang dalam rrangka pencapaian tujuan yang telah ditentukan. Dalam perencanaan terdapat langkah-langkah yang harus ditempuh agar dalam merealisasikan kegiatan dapat berjalan sesuai dengan yang diharapkan.

Langkah-langkah tersebut meliputi :

a) Menentukan dan merumuskan tujuan yang hendak dicapai.

b) Meneliti masalah atau pekerjaan yang akan dilakukan.

c) Mengumpulkan data dan informasi yang diperlukan.

d) Menentukan tahap atau rangkaian kegiatan.

e) Merumuskan bagaimana masalah-masalah itu akan dipecahkan dan bagaimana pekerjaan-pekerjaan itu akan diselesaikan.

Jadi merencanakan berarti pula memikirkan tentang penghematan tenaga, penghematan biaya dan waktu, juga mengatasi kesalahan yang mungkin terjadi 
dan menghindari adanya tugas atau pekerjaan yang rangkap dapat menghambat jalannya penyelesaian.

b. Pengorganisasian (organizing)

Pengorganisasian merupakan aktivitas menyusun dan membentuk hubunganhubungan kerja antara orang-orang sehingga terwujud suatu kesatuan usaha dalam pengorganisasian terdapat adanya pembagian tugas, wewenang dan tanggung jawab secara terperinci menurut bidang dan bagian, sehingga terciptalah adanya hubungan-hubungan kerjasama yang harmonis dan lancar menuju pencapaian tujuan yang telah ditetapkan. Proses pengorganisasian mempunyai beberapa manfaat, antara lain yaitu:

a) Dengan adanya pengorganisasian maka setiap unit akan selalu merasa dalam wadah yang sama, yakni organisasi.

b) Antara unit yang satu dengan unit yang lain dapat diketahui dengan jelas batas-batas wewenang dan tanggung jawabnya.

c) Dengan adanya struktur organisasi dapat diketahui jalur hubungan kerja, baik yang sifatnya vertical maupun horizontal.

Yang perlu diperhatikan dalam pegorganisasian ialah bahwa pembagian tugas, wewenang dan tanggung jawab hendaknya disesuaikan dengan pengalaman, bakat, minat, pengetahuan dan kepribadian masing-masing orang yang diperlukan dalam menjalankan tugas-tugas tersebut. Dengan demikian pentingnya suatu organisasi sebagai alat.

c. Bimbingan atau pengarahan (direction)

Apabila suatu organisasi sudah terbentuk dan berfungsi, setiap personil sudah melakukan kegiatan-kegiatan sesuai dengan wewenang dan tanggung jawab masing-masing, maka diperlukan tindakan pemberian bimbingan dan pengarahan sebagai salah satu kegiatan administratif.

Bimbingan dan pengarahan harus dilakukan secara berlanjut agar seluruh kegiatan selalu terarah pada pencapaian tujuan yang telah dirumuskan. Bimbingan berarti memelihara, menjaga dan memajukan organisasi melalui setiap personil, baik secara struktual maupun fungsional agar setiap kegiatannya tidak terlepas dari usaha untuk mencapai tujuan. Yang dimaksud dengan pengarahan adalah suatu usaha untuk memberikan penjelasan, petunjuk seta pertimbangan dan bimbingan terhadap para petugas yang terlibat, baik 
secara struktual maupun fungsional agar pelaksanaan tugas dapat berjalan dengan lancar.

Menurut Siswanto, pengarahan berarti menentukan bagi bawahan tentang apa yang harus mereka kerjakan atau tidak harus mereka kerjakan. Untuk itu pengarahan yang dilakukan oleh pimpinan kepada para personil sebelum mereka melaksanakan tugasnya, akan sangat berguna bagi kelancaran penyelesaian tugas. Pengarahan-pengarahan tersebut dapat berupa:

a) Penjelasan tentang apa, mengapa dan bagaimana tugas.

b) Urutan pioritas penyelesaian

c) Prosedur kerja.

d) Sarana dan sumber yang dapat dimanfaatkan.

e) Pihak-pihak yang berkait dengan urusannya, baik langsung maupun tidak langsung.

f) Bagaimana melakukan penilaian terhadap penyelesaian tugas tersebut. Dalam realitasnya kegiatan bimbingan dapat berbentuk sebagai memberikan dan menjelaskan perintah, memberikan petunjuk melaksanakan suatu kegiatan, dan lain sebagainya.

\section{Tugas Administrasi dalam Kegiatan Adminitrasi Umum}

Menurut Dr. Durotul Yatimah,M.PD. (2013:45) sesuai dengan tugas pokok dan fungsinya, seorang sekretaris harus senantiasa memiliki kesiapan untuk membantu pimpinan dalam merencanakan dan menyelenggarakan berbagai kegiatan organisasi, baik yang bersifat pokok maupun penunjang.

Beberapa tugas sekretaris organisasi yang berhubungan dengan rangkaian kegiatan penataan terhadap pekerjaan pokok atau aktivitas penunjang administrasi umum adalah sebagai berikut.

a. Membantu pimpinan dalam memimpin dan menjalankan wewenang organisasi dalam bidang administrasi.

b. Membantu melaksanakan fungsi manajemen tertinggi dalam melakukan segenap rangkaian kegiatan penataan terhadap pekerjaan pokok agar pencapaian tujuan organisasi dapat berjalan lancar.

c. Menyiapkan bahan-bahan dan perumusan-perumusan mengenai haluan induk, peraturan, keputusan, dan intruksi yang akan diharpakan oleh pimpinan. 
d. Melakukan pengolahan dan penelaahan terhadap haluan induk yang telah ditetapkan untuk dilaksanakan.

e. Mengumpulkan, mengolah, dan mengajukan berbagai masalah inormasi, atau saran kepada pimpinan untuk dijadikan bahan dalam membuat keputusan atau melakukan tindakan.

f. Melakukan penelitian serta pencatatan rencana kerja dan hasil kerja yang telah dicapai oleh organisasi.

g. Menandatangani surat ke luar atas nama pimpinan.

h. memberikan disposisi surat masuk kepada tiap-tiap pejabat pembatunya sepanjang tidak perlu disampaikan kepada pimpinan.

i. Menghadiri rapat yang diselenggarakan oleh organisasinya.

j. Memimpin rapat sekretaris.

k. Menyampaiakn laporan secara berkala atau sewaktu-waktu diperlukan.

1. Mewakili pimpinan apabila yang bersangkutan sedang berhalangan.

m. Menyelenggarakan tata kepegawaian seperti menelaah berbagai peraturan kepegawaian, menyusun informasi (mempelajari pembagian tugas para pejabat. Menghitung volume kerja berbagai satuan organisasi, mempelajari kemungkinan tambahan aktivitas tiap satuan organisasi, menentukan berbagai jabatan yang diperlukan untuk melakukan tambahan aktivitas, menentukan jumlah jabatan yang diperlukan.), mengusulkan pengangkatan menjadi pegawai negeri, mengajukan permintaan kartu pegawai negeri sipil, mengajukan usul kenaikan pangkat, mengurus keperluan pegawai dan keluarganya, melayani permintaan cuti sakit, mengurus penataran pegawai, meningkatkan kesejahteraan pegawai, dan lain-lain sebagainya.

n. Menyelenggarakan tata keuangan.

o. Menyelenggarakan tata perbekalan seperti menyusun kebutuhan barang tahan lama, mengadakan barang yang tahan lama, mengadakan barang habis pakai, mencatat barang tahan lama, mencatat barang habis pakai, memelihara barang tahan lama, mengatur penyusunan tata ruang, menjaga kebersihan ruangan, dan mengatur pemakaian kendaraan dinas.

p. Menyelenggarakan tata warkat seperti memproses surat masuk-keluar, menyusun konsepsurat, menyimpan dan memelihara surat, mengetik surat, 
menggandakan surat, mengatur pengantar surat, melayani peminjaman surat, dan menyusun arsip.

q. Menyelenggarakan penyempurnaan organisasi dan tata kerja.

r. Memikul tanggung jawab terakhir atas tercapainya tujuan penunjang dengan sebaik-baiknya.

s. Melakukan aktivitas-aktivitas lain atas perintah atasan.

\section{Kedudukan Sekretaris dalam Proses Administrasi}

Menurut Dr. Durotul Yatimah,M.PD. (Kesekretarisan modern \& administrasi perkantoran,2013:38) dalam kaitannya dengan tugas-tugas admnitrasi, sekretaris memiliki kedudukan sebagai berikut.

a. Koordinator segenap kegiatan tata usaha.

b. Pembantu pimpinan dalam perencanaan dan penyelenggaraan transaksi dengan pihak luar.

c. Senantiasa siap mengerjakan kegiatan-kegiatan yang berhubungan dengan kedinasan sehingga dapat memberi keleluasaan kepada pimpinan dalam melaksanakan tugas-tugas manajemennya.

d. Dinamis, aktif, kreatif, dan inisiatif untuk memajukan perusahaan.

e. Memiliki skill yang dapat menunjang kemajuan perusahaan, seperti bahasa asing, kesekretarisan, komputer, perbankan, dan lain-lain.

\section{Pengertian Faktur}

Sebagai sebuah organisasi yang bertujuan memperoleh laba, perusahaan berusaha untuk menghasilkan barang dan jasa yang akan dijual kepada para konsumen dengan harga yang menguntungkan. Agar tujuan itu tercapai, suatu perusahaan membutuhkan data-data pembukuan keuang yang lengkap sehingga tidak terjadi salah hitung dalam menentukan harga. Untuk bisa mempunyai laporang keuangan yang baik, dibutuhkan bukti-bukti transaksi yang akurat. salah satu jenis bukti transaksi adalah faktur.

Faktur Penjualan atau dalam istilah asingnya yaitu Sales Invoice adalah lembar bukti tagihan atau bukti transaksi kepada pelanggan atas pembelian suatu barang/jasa. Faktur Penjualan biasanya dikirim oleh pemasok bersamaan dengan atau setelah pengiriman barang/jasa. Tidak ada bentuk baku faktur di mana pun sehingga perusahaan dapat mengubah sesuai bagian-bagian faktur sesuai dengan keperluan. 
Seiring dengan perkembangan zaman dan adanya kampanye penyelamatan bumi, faktur penjualan kini telah ber-evolusi secara digital. Tanpa perlu adanya pencetakan di lembaran kertas, faktur elektronik ini sudah ditetapkan sah sebagai bukti transaksi bahkan sekaligus sebagai faktur pajak. Berikut ini adalah beberapa pengertian dan definisi faktur:

a. Faktur adalah perhitungan penjualan kredit yang diberikan oleh penjual kepada pembeli. Biasanya faktur dibuat rangkap tiga. Lembar pertama diserahkan kepada pembeli, lembar kedua disimpan penjual setelah ditadatangani oleh pembeli, yang kelak akan digunaka sebagai lampiran kuitansi untuk menagih. Lembar ketiga dibiarkan melekat pada buku faktur yang oleh penjual disebut "copy faktur penjualan"

b. Faktur adalah sebuah perincian pengiriman barang yang mencatat daftar barang, harga, dan hal-hal lain yang biasanya terkait dengan pembayaran.

c. Faktur adalah perhitungan penjualan dengan perhitungan pembayaran kemudian. Biasanya pembuatan faktur dilakukan rangkap 3. Salinan pertama berwarna putih dan diserahkan kepada pembeli. Salinan kedua disimpan penjual setelah ditandatangani pembeli dan akan dijadikan lampiran saat penagihan dikemudian hari. Sedangkan salinan ketiga disimpan di dalam buku faktur.

d. Faktur adalah salah satu dokumen dasar sebagai bukti pencatatan bagi perusahaan penjual dan perusahaan pembeli. Faktur ini merupakan bukti transaksi penjualan yang dilakukan secara kredit dan biasanya dibuat rangkap.

Beberapa hal yang perlu diperhatikan dalam pembuatan Invoice/Faktur adalah sebagai berikut :

a) Invoice faktur dibuat sesuai dengan barang yang telah diserahkan/diterima dengan baik oleh customer. Adakalanya barang yang telah dikirim, ditolak sebagian atau diterima bersyarat oleh customer. Karena itu Invoice faktur dibuat setelah Delivery Order ditandatangani oleh penerima.

b) Satu Order pembelian dapat direalisasikan dalam satu transaksi dan dapat juga direalisasikan secara bertahap. Banyak kebijakan perusahaan yang menetapkan bahwa pembayaran akan dilakukan setelah order pembelian telah terealisasikan secara keseluruhan sehingga apabila terdapat beberapa kali, maka invoice / faktur hanya dibuat apabila order penjualan telah dipenuhi secara keseluruhan. Untuk itu diperlukan informasi ringkas mengenai dokumen-dokumen yang terkait dengan tagihan tersebut. Keperluan tersebut dibutuhkan baik bagi penerima tagihan maupun pembuat invoice. 
c) Pembuatan Invoice secara otomatis akan meng-update buku piutang penjualan. Dengan ini dapat diartikan pembuat invoice adalah bagian yang juga mencatat piutang.

d) Dalam prosedur internal kontrol system akuntansi metode manual disarankan untuk membuat invoice di atas formulir dengan nomor urut tercetak namun dengan sistem akuntansi komputer semakin banyak perusahaan menggunakan nomor komputerisasi. Keunggulan penggunaan nomor tercetak menjamin tidak terjadinya nomor ganda dalam pembuatan Invoice namun apabila terjadi kegagalan, nomor transaksi dicatat pada nomor berikutnya sesuai dengan nomor urut dokumen tercetak. Bila menggunakan nomor urut yang ditulis komputer perlu pengawasan lebih ketat karena memungkinkan terjadinya invoice ganda yang dapat menimbulkan kerugian perusahaan.

\section{Fungsi Faktur}

Fungsi faktur dapat Fungsi Faktur adalah sebagai berikut :

a. Pembeli datang untuk mengetahui tentang jumlah yang harus dibayarkan kepada penjual.

b. Pembeli dapat memeriksa harga faktur terhadap kutipan/harga proforma invoice. Jika perbedaan apapun pembeli bisa mengatasinya dengan penjual.

c. Nota membantu pembeli untuk memperbaiki harga untuk dijual kembali.

d. Faktur membantu pembeli untuk memverifikasi barang aktual yang diterima.

e. Nota membantu untuk mempersiapkan nota debet atau nota kredit.

f. Nota dapat digunakan sebagai bukti di pengadilan.

g. Faktur memfasilitasi penjual dalam mengecek total volume penjualan dan memverifikasi keseimbangan saham.

h. Nota memungkinkan pembeli untuk membuat entri dalam pembukuan.

i. Nota memungkinkan penjual untuk membuat entri yang diperlukan dalam buku penjualan dan jumlah pelanggan buku.

j. Nota membantu pembeli untuk mengetahui tanggal jatuh tempo tepat pembayaran kepada penjual.

\section{Kegunaan Faktur}

Secara perinci kegunaan faktur dapat diuraikan sebagai berikut: 
a. Sebagai informasi barang/jasa yang dibeli oleh pelanggan.

b. Sebagai informasi nilai tagihan dan termin pembayaran yang harus dibayar oleh pelanggan.

c. Pelanggan dapat memperbaiki barang/jasa dan atau nilai yang dibeli jika yang tercantum tidak sesuai dengan pesanan.

d. Rujukan yang absah apabila barang/jasa yang tercantum akan dijual lagi ke pihak lain.

e. Rujukan yang absah untuk memasukkan transaksi ke pembukuan keuangan.

f. Rujukan yang absah sebagai faktur pajak untuk kasus-kasus tertentu.

\section{Tugas Sekretaris dalam Administrasi Fakturis}

Salah satu tugas sekretaris adalah berkaitan dengan administrasi. Dalam administrasi seorang sekretaris melakukan tugas-tugas umum administrasi dan salah satunya sebagai administrasi fakturis. Seorang sekretaris yang bertanggung jawab dan efektif maupun efesien dalam bekerja akan mampu dalam menyelesaikan tugas administrasi fakturisnya. Efektif artinya tujuan administrasi fakturis tercapai. Efesien berarti bisa menyelesaikan dengan cepat dan tidak membutuhkan banyak biaya.

Administrasi fakturis berarti usaha untuk mencapai tujuan kegiatan fakturis dalam memproses faktur. Saat menyelesaikan faktur tugas sekretaris adalah sebagai fakturis, yaitu orang yang bertanggung jawab akan memproses pembuatan faktur penjualan dari pengisian tipe-tipe barang order, pengisian sales dan discount setiap pelanggan. Dalam menangani proses faktur seorang sekretaris harus mengikuti prosedur yang telah ditentukan oleh perusahaan. Untuk memproses faktur dengan baik seorang sekretaris harus melakukan dengan cara sebagai berikut :

a. Sebelum memproeses faktur, seorang sekretaris meng-check limited piutang customer

b. Meng-check daftar-daftar barang yang di order pada kartu stock

c. Meng-check discount tambahan jika ada

Setelah semuanya telah diperhatikan maka seorang sekretaris dapat memproses faktur. Faktur penjualan telah selesai diproses maka seorang sekretaris harus meminta persetujuan dari suppervisor untuk ditanda tangani dan di cap stemple peruahaan.

Tugas sekretaris sebagai administrasi fakturis selanjutnya adalah mengolah kembali faktur penjualan menjadi faktur penagihan. Faktur penagihan adalah suatu dokumen penting yang berupa nota penjualan yang mempunyai batas pengkreditan sesuai 
dengan tanggal jatuh tempo. Dalam mengolah kembali faktur penjualan menjadi faktur penagihan dapat dibuat monitouring penjulan customer, yang disesuaikan dengan tanggal jatuh tempo yang berdasarkan rumus-rumus yang telah ditetapkan oleh perusahaan.

\section{F. Pembahasan Dan Hasil}

\section{Sejarah dan Aktivitas Perusahaan}

PT Dwi Anugerah Abadi adalah perusahaan yang bergerak dibidang pendistribusian komponen otomotif aftermarket. PT Dwi Anugerah Abadi yang disingkat namanya jadi DAA GROUP secara resmi didirikan pada tanggal 1 September 2007. Terletak di daerah Tangerang Selatan di jalan Pahlawan Seribu Ruko Tol Boulevard Blok E No.1. BSD City, Serpong. dengan jumlah invenstasi awal sebanyak Rp 1.000.000.000.000,- (1 Miliar).

Izin usaha perdagangan pertama yaitu dengan No.503-000106-BP2T/3008/PK/I/2013 Atas nama PT Dwi Anugerah Abadi. Fondasi awal bisnis kami didasarkan atas prinsip kepercayaan yang sudah terjalin cukup lama yang diberikan oleh pemasok kami kepada buiness owner. Pengembangan bisnis kami selanjutnya, kami kelola secara berkesinambungan dengan menjaga hubungan baik dengan mitra usaha kami, yaitu : supplier, dealer dan customer.

\section{Visi :}

Visi kami ialah ingin menjadikan perusahan terdepan sebagai perusahaan distribusi komponen otomotif.

\section{Misi :}

Misi kami selalu memberikan yang terbaik untuk customer dengan mengedepankan kualitas dan daya saing produk, serta service yang baik.

\section{Sumber Daya Manusia}

Dalam pengembangan bisnis, kami percaya sumber daya manusia memegang peranan dominant dan merupakan bagian yang tak dapat dipisahkan dari kegiatan bisnis perseroan, kami memberikan perhatian lebih bagi mereka agar dapat menyeimbangkan kehidupan mereka dan pekerjaannya sehingga dapat mengembangkan potensi individu yang nantinya dapat memberikan kontribusi bagi perseroan dan masa depan individu tersebut. Sumber daya yang dimaksud 
seyogyanya memiliki tanggung jawab dan kejujuran dalam mengembangkan tugas yang diberikan kepadanya tanpa melunturkan nilai-nilai moral yang ada.

\section{Pembahasan}

PT Dwi Anugerah Abadi memperkerjakan kurang lebih 20 karyawan yang terdiri dari pria dan wanita dengan latar pendidikan yang berbeda. Status kepegawaian di PT Dwi Anugerah Abadi juga dibagi menjadi 2 kategori yaitu karyawan tetap dan karyawan kontrak.

\section{Jam Kerja Karyawan di PT Dwi Anugerah Abadi}

Jam kerja PT Dwi Anugerah Abadi disesuaikan dengan standar yang sudah ditetapkan, yaitu :

a. Jam kerja karyawan kantor, dimulai pukul 08.00 sampai 17.00 setiap Senin sampai dengan Sabtu. Selain itu, dalam waktu kerja tersebut sudah termasuk jam istirahat standar kerja.

b. Jam kerja karyawan toko, dimulai pukul 08.00 sampai 18.00 Senin sampai dengan Minggu. Selain itu, setiap hari Minggu karyawan toko mendapatkan rolling di hari minggu.

\section{Sarana dan Prasarana di PT Dwi Anugerah Abadi}

PT Dwi Anugerah Abadi dilengkapi dengan sarana dan prasarana yang menunjang kegiatan proses kerja dan memberikan kemudahan pada karyawannya, antara lain :

a. Pendidikan dan pelatihan, PT Dwi Anugerah Abadi menjalankan program pendidikan yang mengacu pada standar DAA Group. Program pelatihan yang diberikan cukup beragam, khususnya pengaplikasian komputer bagi karyawan baru. Pemberian dan pelaksanaan sesuai dengan identifikasi kebutuhan pelatihan.

b. Sarana peribadatan, sarana peribadatan telah disesuaikan dengan mayoritas kepercayaan di Indonesia yaitu disediakan mushola.

c. Ruang makan, ruang makan yang ada di PT Dwi Anugerah Abadi sangatlah berbeda dengan perusahaan lainnya. Karena di PT Dwi Anugerah Abadi kami 
sediakan makan siang untuk karyawan kantor dan toko, sedangkan untuk direktur disediakan khusus.

d. Transportasi, alat transportasi disediakan motor dan mobil truck untuk kegiatan proses kerja bagi karyawan kantor dan toko.

\section{Keterangan untuk produk PT.Dwi Anugerah Abadi}

Setiap produk yang kami distribusikan kepada customer, diproduksi dan telah diuji ketahanannya agar sesuai dengan kebutuhan oleh pemasok yang berkompenten di bidangnya yang mana setiap produk yang diproduksi memiliki kualitas yang tidak diragukan, yang didistribusikan melalui pusat distribusi milik sendiri. Berikut ini adalah rincian produk PT Dwi Anugerah Abadi :

a. Daimaru, produk Brake Shoe, Brake Pad, Brake Lining

b. Neder, produk Suspension Parts dan Wiper

c. Genso, produk Brake Shoe, Brake Pad, Brake Lining

d. Massiv ( XP dan Thunder ), produk Battery

e. Shimatsu, produk Oil Filter, Air Filter, Brake Shoe, Brake Pad, Brake Lining.

\section{Customer dan Mitra PT Dwi Anugerah Abadi}

PT Dwi Anugerah Abadi memandang hubungan yang erat dan saling menguntungkan antara PT Dwi Anugerah Abadi dengan pelanggan dan mitra kerja sebagai hal yang sangat penting dalam mendorong keberhasilan kerja bisnis dan operasionalnya selama ini. Tanpa jalinan kerjasama yang efektif dengan mereka, tidak mungkin PT Dwi Anugerah Abadi berkembang dan mencapai kinerja yang mengesankan bagi customer dan mitra kerja kami. Dengan itu perusaahan kami mempunyai banyak customer dan mitra, berikut perusahaan yang berkerjasama dengan kami :
a. PT Mitra Sukses Mandiri
e.PT Tunggal Laris Gemilang
b. PT Karya Sentosa Jaya
f PT Energy Group
c. PT Banjar Betterindo
g PT Kikijaya Airconindo
d. PT Gutrado Utama Tranding
h.PT Mutiara Denso Sejati 


\section{Struktur Organisasi dan Deskripsi Posisi di PT Dwi Anugerah Abadi}

Menurut Wikipedia struktur organisasi adalah suatu susunan dan hubungan antara tiap bagian secara posisi yang ada pada perusahaan dalam menjalin kegiatan operasional untuk mencapai tujuan.

Menurut (Stone;2005) Deskripsi Posisi adalah pernyataan tertulis yang menjelaskan mengapa pekerjaan ada, apa yang dilakukan pemegang pekerjaan sebenarnya, bagaimana mereka melakukannya dan dalam kondisi apa pekerjaan itu dilakukan. Tidak ada format standar yang digunakan untuk menulis deskripsi pekerjaan; format, pada kenyataannya, tergantung pada preferensi manajemen dan bagaimana deskripsi pekerjaan akan digunakan. Tujuan dan Manfaat deskripsi posisi :

a. Tujuan deskripsi posisi :

a) Konsistensi pekerjaan menjamin kehidupan bisnis yang teratur.

b) Keberhasilan atau kegagalan semua organisasi tergantung pada prinsip : "Adanya Jabatan yang benar yang dilakukan oleh orang-orang yang benar dengan cara yang benar ".

c) Bahwa seperti waktu kita diserap untuk bekerja, oleh karena itu harus ada penyusunan job description yang baku dan benar.

b. Manfaat deskripsi posisi :

a) Membantu atasan dan bawahan mengerti: Mengapa suatu jabatan diadakan dan Apa tujuan utamanya.

b) Sebagai Alat Managemen untuk mengintegrasikan fungsi-fungsi: Performance Management, Staffing \& Selection, Organization Design, Reward System, Career Development \& Training.

\section{STRUKTURAL ORGANISASI DI PT DWI ANUGERAH ABADI}





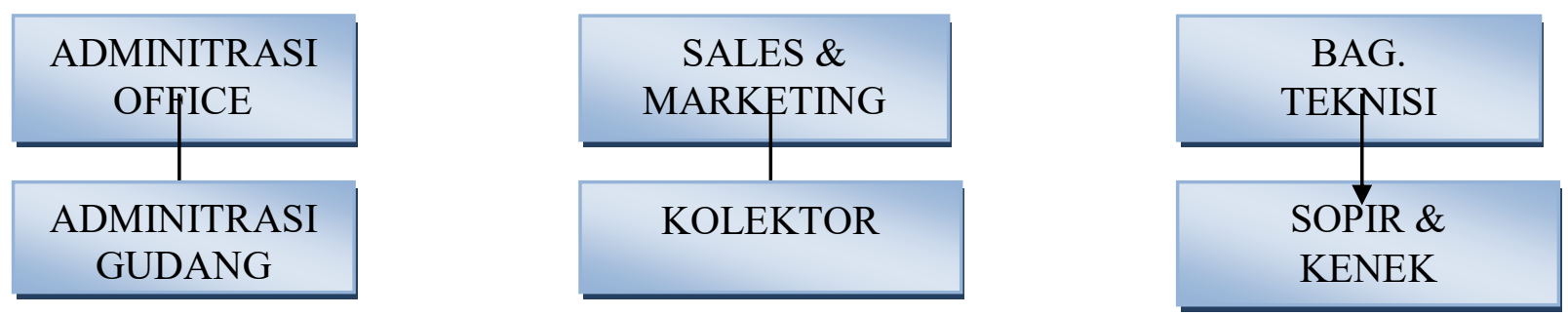

Dari Struktur di atas Mempunyai deskripsi posisi, antara lain :

a. Direktur PT Dwi Anugerah Abadi, mempunyai tugas antara lain :

a) Sebagai pemimpin dalam sebuah rapat umum di perusahaannya.

b) Bertindak sebagai perwakilan organisasi dalam hubungannya dengan dunia luar.

c) Menjalankan tanggung jawab dari direktur perusahaan sesuai dengan standar etika dan hukum, sebagai referensi dalam.

b. Manajer di PT Dwi Anugerah Abadi, mempunyai tugas antara lain :

a) Bertanggung jawab dan mengontrol atas pemesanan barang terhadap pabrik.

b) Bertanggung jawab dan mengontrol para bawahan dan dapat bekerja sama agar terciptanya hubungan kerja yang baik terhadap perusahaan.

c) Bertanggung jawab dalam membuat laporan secara berkala kepada atasannya atas hasil kerjanya beserta analisa permasalahannya secara singkat, padat, dan kongkrit.

c. Sekretaris di PT Dwi Anugerah Abadi, mempunyai tugas antara lain :

a) Bertanggung jawab dan mengurus keperluan direktur yang dibutuhkannya, seperti : mengatur jadwal kesehariannya, mengatur perjalanan dinas, menjadi notulen di saat rapat, dan lain sebagainya.

b) Membuat dan menerima surat keluar dan surat masuk.

c) Menerima telepon dan membuat catatan kecil atau janji temu dengan direktur.

d. Administrasi Office di PT Dwi Anugerah Abadi, mempunyai tugas antara lain :

a) Mencatat orderan sales and marketing dan membuat invoice penjualan.

b) Membuat dan meng-update monitouring penjualan setiap minggunya.

c) Menangani petty cash (kas kecil).

e. Administrasi Gudang di PT Dwi Anugerah Abadi, mempunyai tugas antara lain :

a) Mencari dan meng-check barang yang telah di order toko.

b) Mengawas dan bertanggung jawab atas barang yang telah di packing maupun permintaan barang terhadap pabrik. 
c) Merapihkan dan mencatat kartu stock barang masuk maupun barang keluar.

f. Sales and Marketing di PT Dwi Anugerah Abadi, mempunyai tugas antara lain :

a) Menawarkan produk terhadap pembeli baru maupun pelanggan untuk meng-order barang.

b) Membuat dan bertanggung jawab atas laporan penjualan sales per bulan terhadap perusahaan.

c) Mengontrol setiap pelanggan terhadap piutang penjualan.

g. Kolektor di PT Dwi Anugerah Abadi, mempunyai tugas antara lain :

a) Mengatur perjalanan penagihan piutang toko.

b) Bertanggung jawab akan faktur tagihan dan uang setoran yang dibawa agar tidak hilang.

c) Menagih piutang yang sudah jatuh tempo terhadap toko.

h. Bag.Teknisi di PT Dwi Anugerah Abadi, mempunyai tugas antara lain :

a) Mengontrol dan meng-check setiap claim barang dari toko maupun pembeli toko.

b) Mengontrol dan meng-check kendaraan operasional perusahaan.

c) Menjaga toko, menjual dan memasang aki jika pembeli toko datang ataupun order by phone.

i. Sopir dan Kenek di PT Dwi Anugerah Abadi, mempunyai tugas antara lain :
a) Bertanggung jawab akan setiap barang yang akan dikirim.
b) Bertanggung jawab atas faktur kiriman agar tidak hilang.
c) Manaikkan atau menurunkan barang yang dikirim.

\section{Tempat dan Pembahasan Hasil}

3.3.1 Tempat dan waktu pelaksanaan Praktek Kerja Lapangan

a. Tempat dan waktu pelaksanaan praktek kerja lapangan

Pelaksanaan praktek kerja bertempat di PT Dwi Anugerah Abadi. Pelaksanaan praktek kerja lapangan berlangsung sejak tanggal 1 Mei 2014 sampai dengan 30 Juni 2014.

\subsubsection{Pembahasan dan Hasil}

Pekerjaan administrasi fakturis merupakan salah satu kegiatan penting dalam mencapai tujuan di PT Dwi Anugerah Abadi. Dalam kurun waktu yang sangat singkat tersebut, cukup banyak hal yang harus diperhatikan oleh 
sekretaris. Pada saat itu sekretaris di tunjuk sebagai administrasi fakturis. Dalam keseharian sekretaris, ketika mendapatkan tugas dari pimpinan, seorang sekretaris harus mampu menangani hal-hal yang bersinggungan dengan administrasi. PT Dwi Anugerah Abadi merupakan perusahaan yang sangat berkembang pesat sehingga tugas administrasi sangat berperan penting dalam menunjang berjalannya sistem yang telah ditentukan PT Dwi Anugerah Abadi sendiri.

Tugas sekretaris di PT Dwi Anugerah Abadi yang bersinggungan dengan administrasi yaitu menginput orderan dari sales berupa faktur penjualan yang kemudian di tanda tangani oleh manager perusahaan. Setelah faktur penjualan selesai diproses oleh sekretaris, faktur penjualan tersebut diserahkan kepada admin gudang untuk dipersiapkan barang-barang dan di check sesuai dengan faktur penjualanan.

Hal-hal yang harus diperhatikan oleh sekretaris dalam memproses faktur adalah meng-check piutang toko-toko sebelum faktur diproses, meng-check stock barang-barang yang diorder oleh toko, kemudian meng-check diskon masingmasing toko. Setelah semuanya di check dan tidak ada masalah dengan piutang dan stock barang, dengan itu faktur dapat diproses oleh sekretaris. Setelah faktur penjualan sudah selesai diproses dan dapat dikirim, adapun hal-hal yang harus diperhatikan yaitu:

a. Penjadwalan kiriman barang-barang.

b. Cara pengiriman yang dipilihnya, kendaraan yang dipakai (truck atau motor)?

c. Biaya akomodasi pengiriman barang.

Contoh faktur penjualan : 


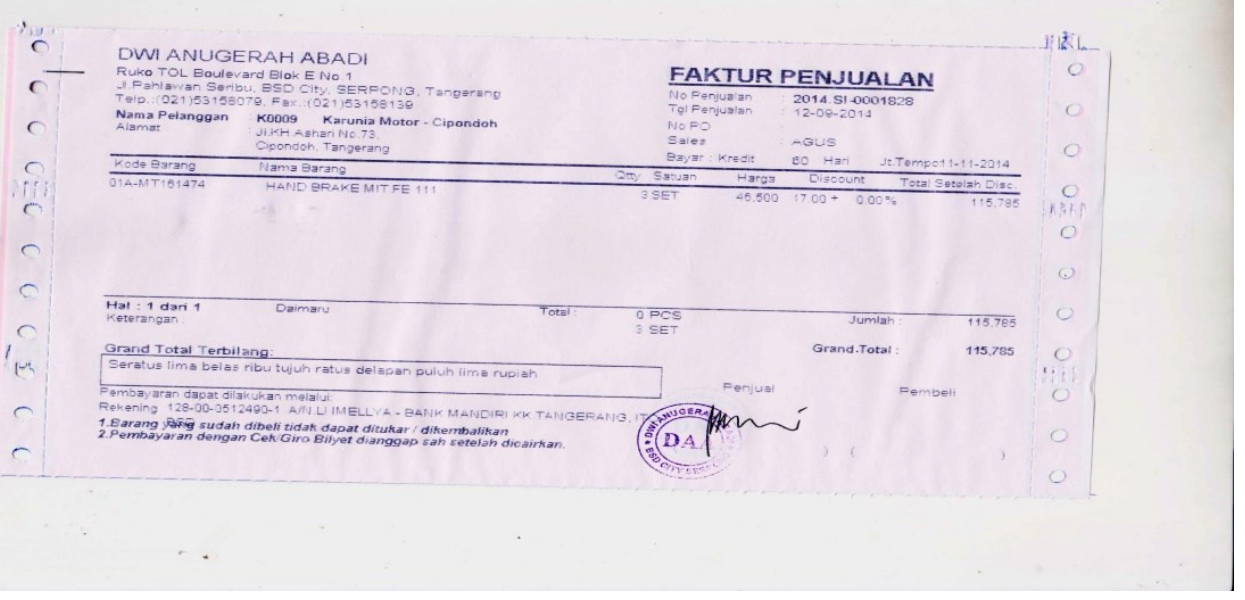

Faktur penjualan berisi tanggal penjualan, nomor penjualan, nomor PO (jika ada), nama sales, nama pelanggan, alamat pelanggan, sistem bayar (cash atau credit, jika credit tempo 60 hari), tanggal jatuh tempo faktur, tipe-tipe barang, jumlah barang, harga barang, discount harga, dan grand total. Faktur penjualan terdiri dari tiga rangkap, faktur putih untuk diarsip, jika sudah jatuh tempo maka faktur tersebut dikeluarkan sebagai faktur tagihan. Faktur merah diserahkan untuk toko saat pengiriman dan faktur kuning diarsip oleh admin gudang untuk mencatat barang-barang keluar.

Contoh faktur bukti retur penjualan :

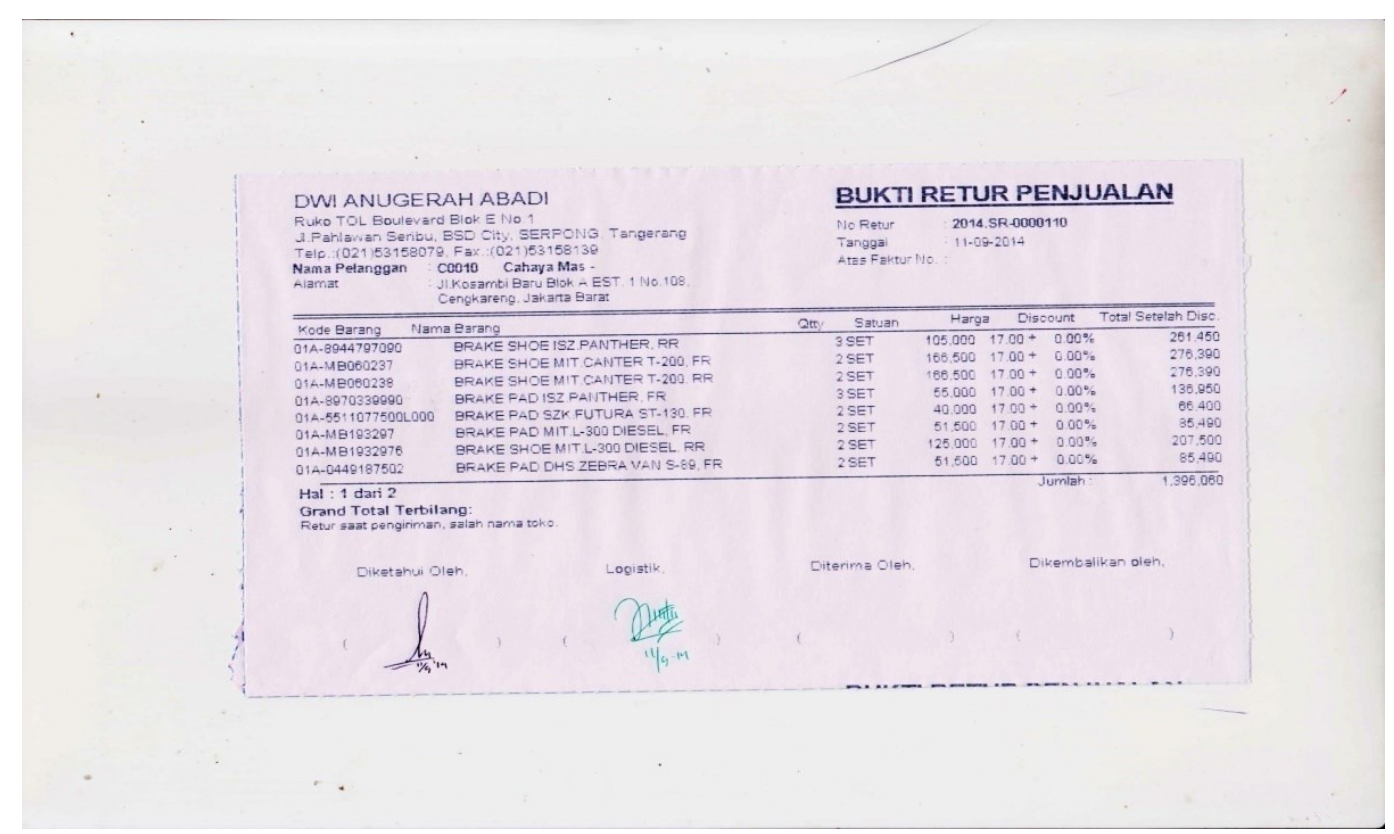

Bukti retur penjualan berisi tanggal retur penjualan, nomor retur, atas nomor faktur penjualan, nama pelanggan, alamat pelanggan, tipe-tipe barang yang diretur, jumlah barang, harga barang, discount barang, grand total, dan 
keterangan kenapa barang tersebut diretur. Faktur bukti retur penjualan terdiri dari tiga rangkap, faktur putih dilampirkan dengan faktur kuning penjualan untuk lampiran setoran, faktur merah diserahkan kepada toko untuk arsip toko, dan faktur kuning diserahkan kepada admin gudang untuk mencatat pengembalian barang.

Semua hal-hal yang ada di atas bertujuan untuk :

a. Menjaga nama baik perusahaan.

b. Meningkatkan nama baik divisi.

c. Mendukung usaha-usaha pemasaran.

Dari semua uraian yang ada, dapat di ketahui peranan sekretaris mulai bersinggungan dengan beberapa tugas adminitrasi fakturis yang berfungsi untuk menetukan tujuan organisasi dan menjalankan kebijakan yang telah di buat oleh manajemen PT Dwi Anugerah Abadi.

\section{G. Kesimpulan Dan Saran}

\section{Kesimpulan}

Peran sekretaris dengan administrasi fakturis adalah sama-sama melakukan pekerjaan kantor seperti mengelola data, menginput data, mengetik dan lain sebagainya. Selain itu tugas dan tanggung jawab sekretaris dan adminitrasi fakturis sangat menunjang berjalannya sistem dari sebuah lembaga atau perusahaan. Karena tanpa adanya sekretaris dan administrasi sistem atau kegiatan dalam sebuah perusahaan atau organisasi tidak akan berjalan dengan tertib dan lancar.

Perbedaan dari ke-duanya ialah sekretaris harus dapat mengatur pekerjaan yang telah diberikan oleh pimpinan ketika pimpinan tidak bisa meng-handle pekerjaannya. Sedangkan adminitrasi adalah rangkaian kegiatan yang berupa proses pengelolaan usaha dalam suatu organisasi atau lembaga untuk mencapai tujuan bersama yang telah ditetapkan sebelumnya agar efektif dan efisien.

\section{Saran}

Berdasarkan uraian diatas penulis mencoba untuk mengeluarkan beberapa saran yang mungkin kiranya dapat diterima atau bermanfaat sebagai bahan untuk kemajuan seorang sekretaris dalam bekerja. Untuk saran tersebut penulis sampaikan sebagai berikut :

a. Kepada pihak Organisasi 
a) Pengetahuan dan keterampilan yang dimiliki Sekretaris dalam administrasi fakturis PT Dwi Anugerah Abadi harus lebih di tingkatkan lagi agar tidak mengalami kesulitan dalam melaksanakan tuga-tugas rutin. Dan sebaiknya juga mengikuti prosedur administrasi fakturis yang telah ditetapkan.

b) Seorang sekretaris dengan adminitrasi harus belajar dan mencari lagi informasi untuk meningkatkan pengetahuan agar bisa lebih berkembang.

c) PT Dwi Anugerah Abadi dalam pembagian tugas karyawan masih kurang baik, maka di atur kembali pembagian tugas-tugas yang sudah ada agar dapat cepat terselesaikan.

b. Kepada pihak Universitas Pamulang

Perlu menjalin hubungan dengan baik dengan instansi lain agar mahasiswa dapat dengan mudah ditempatkan untuk pelaksanaan magang dan perekrutan untuk nantinya dapat menjadi karyawan di perusahaan guna sebagai lapangan pekerjaan. 


\section{Daftar Pustaka}

Lawalata, Caroline, F.Ch. (Akademia Permata,2012)Panduan Lengkap Pekerjaan Sekretaris. Medan

http://zahiraccounting.com/id/blog/faktur-penjualan-bukti-otentik-suatu-transaksi/ diunduh pada 16 Juni 2014

Herlambang, Susatyo (Pustaka Baru,2014)Manajemen Kesekretarisan.Yogyakarta

Sutarto (Salemba Empat,2002)Administrasi Perkantoran.Yogyakarta

The Liang Gie (Liberty,2007)Administrasi Perkantoran Modern Edisi KeempatDengan Tamabahan.Yogyakarta

Ernawati Ursula, Dra (Graha Ilmu,2004)Pedoman Lengkap Kesekretarisan. Yogyakarta

Durotul, Yatimah (Pustaka Setia,2009) Kesekretarisan Modern \& Administrasi Perkantoran. Bandung 
